\title{
Electronic submission will be available from April 2008 with online system Editorial Manager ${ }^{\circledR}$
}

(c) The Japanese Society for Hygiene 2008

Environmental Health and Preventive Medicine is pleased to announce the launch of its new online manuscript submission and tracking system. The system will go live in April 2008.

http://www.editorialmanager.com/ehpm/

Editorial Manager ${ }^{\circledR}$ makes it possible for authors to submit manuscripts via the Internet, provides online peer review services, and tracks manuscripts through the review process. Key features include automatic conversion of authors' submissions into PDF format as well as supporting submissions in various file formats and special characters.

After the system goes into operation in April 2008, authors are requested to use Editorial Manager ${ }^{\circledR}$ for all submissions of new manuscripts.

New Information for Authors for online submission will be available at the end of March at the Environmental Health and Preventive Medicine Web site: http://www. springer.com/EHPM. 